\title{
Logging the globe: The changing context for Canadian forestry ${ }^{1}$
}

\author{
by Patricia Marchak
}

My primary objective is to describe the nature of global changes in the location of the forest industry. I will also argue that Canadian companies have never been major players in international forestry, and have acted primarily as staples providers for more advanced economies. In the contemporary situation, where new companies in countries that have not previously been engaged in industrial forestry are now becoming competitive, Canadian companies have been slower to restructure their operations than northern European companies. I will express scepticism about the wisdom of continued, and in Alberta, expansion of, dependence on the remaining natural forest cover in Canada.

\section{Prior to the 1970s}

Canada used to be one of the northern countries - along with Sweden, Finland, and Norway - that produced pulp and dimensional lumber for larger metropolitan countries: the United States in the case of Canada, and Western Europe for Sweden and Finland. We produced newsprint but hardly any finer grades of paper. Because advanced wood products met with tariff barriers at the U.S. border, and because the U.S. markets for dimensional lumber and pulp were strong throughout most of the post-war era, there was no incentive to diversify our products or our market destinations. Many of our major companies were owned by parent firms in the United States, and very few Canadian-owned companies were listed, none in the top ranks, of Pulp and Paper International's or other annual world rankings of forest companies.

During this same post-war period, Japan became the second largest paper producer in the world. But Japan had to obtain raw materials from elsewhere because its four small islands had nowhere near sufficient wood supplies to meet the paper demand of its population. Almost half of the deficiency was met by recycled newsprint purchased on international markets, and the remainder was imported from North America as well as many other areas. When countries put log export bans in place, Japanese companies sought wood-chips, and when those supplies were curtailed, they began to look to other countries where they could establish pulp mills to supply their paper mills in Japan.

Japanese construction companies also purchased tropical logs from the Philippines, Indonesia, Malaysia, and other neighbours during this period.

\section{The 1970s and the 1980s}

Indonesia imposed an export ban on logs in 1975, and was successful in establishing a domestic plywood industry

\footnotetext{
${ }^{1}$ Paper presented at the Forest Industry Lecture Series, College of Renewable Resources, University of Alberta, Edmonton, Alberta, March 22, 2001. This paper is based on the author's book, Logging the Globe. McGillQueen's Press, Montreal (1995).

2Department of Anthropology and Sociology, University of British Columbia, 6303 NW Marine Drive, Vancouver, British Columbia V6T 1Z1. E-mail: pmarchak@interchange.ubc.ca
}

that became the largest supplier in the world. Thus, Indonesia initiated the movement in Southeast Asia toward a developed forest industry, in contrast to miscellaneous logging operations conducted primarily by non-nationals. Other tropical countries followed suit, but Japanese logging operations continued into the 1990s on Sabah, Sarawak, and PapuaNew Guinea.

In the pulp and paper sector,

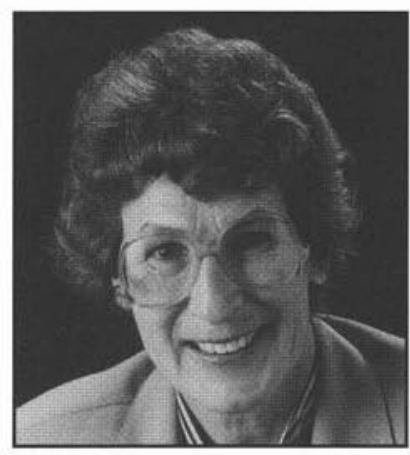

Patricia Marchak several changes occurred during the 1970s and 1980s:

1. Research on pulping technologies improved the utility of hardwoods for pulps of good quality for diverse paper products.

2. The coniferous trees of northern temperate forests were declining in availability. This was not necessarily because of overcutting and failure to replant, though I would argue that this was the case in British Columbia prior to the mid-1980s. After that period, and in direct response to the claim by American companies that Canadian governments were subsidizing the industry, the federal and provincial governments provided substantial, short-term financing to replant the "notsufficiently restocked" lands. The newly replanted lands, however, will not come on stream for commercial purposes until the middle of the $21^{\text {st }}$ century. Since the early $1990 \mathrm{~s}$, forest companies have been obliged to finance the replanting of trees on logged-over lands, and thus the cost of forestry in B.C. has risen substantially.

Declining availability of coniferous timber was because the valleys had been cleared out and the remaining forests were relatively inaccessible, or logging them was no longer economically feasible. Second growths do not produce the same quantity or quality as natural forests, and northern coniferous forests take a good 80 years to reach commercially mature size (Marchak et al. 1999). Investors are not eager to tie up their money in replanting such a forest, especially if there are other, faster crops that will serve the same purpose. And that became the case.

3. While the northern forests were diminishing as a source of wood, pine plantations in the southern United States and many other regions of the world were found to be good sources of wood for both construction and pulp. They could reach maturity within 15 to 35 years, depending on intended use, and some U.S. firms began to move from the northwest coast to the southeastern regions.

4. Biotechnology developed new hybrids and cloning techniques for a number of fast-growing trees, eucalyptus most particularly, but also albizzia, acacia, gmelina and other species. These could be grown in southern sub-tropical and tropical regions. The Eucalyptus globulus reaches commercial 
maturity in seven years. It can be coppiced and will produce three full crops in a 21-year period. It is the favoured tree in Brazil. Acacia is the tree of choice on the island of Sumatra, Indonesia, because it provides a larger canopy for soil protection.

5. An environmental movement emerged, and while it was still feeble in the 1970s, it had become a force to deal with in the 1980s. Public opinion in the northern countries was moving away from complacency about logging old-growth forests and about pulpmill emissions. Where, earlier, there were at most three decision-making institutions in the business - government, the companies, and the unionsnow there were many, including environmental NGOs, indigenous people's councils with land claims, and communities affected by forest policies.

6. And finally, new markets were emerging throughout Asia, Latin America and Africa. The literacy level in countries that had earlier consumed very small quantities of paper products was steadily increasing, and advertising, newspapers, books, tissues, and computer papers were now higher demand products.

\section{The Beginning of a Global Forest Industry}

These developments led to a search for land suitable for the growing of the new pulpwood species in southern regions. New Zealand and Chile planted Pinus radiata, a relatively fast-growing species suitable for pulp. The Iberian Peninsula became one of the first regions used for large-scale eucalyptus plantations. Southeast Asia became another possible growth region. In due course, it became clear that Brazil was the next major source of pulpwood, and an enormous growth in eucalyptus plantations has occurred on an annual basis since the late 1970s. These new sources of wood are the basis for new paper industries in Brazil itself, and in purchasing countries such as Korea, Singapore, and Taiwan, that, like Japan, must source their raw material elsewhere.

Japanese companies bought into these new sources, either in sawmills with market contracts for their wood-chips, as in southern Chile, or in pulp mills in Chile, Brazil, and Canada. Two large pulp mills - one chemical and one thermo-mechanical-were situated in the B.C. interior town of Quesnel nearly a quarter of a century ago. They depend on wood-chips provided by a number of nearby sawmills. The sawmills already had the forest tenures for the region, and the pulp mills owned no woodlands operations. Incidentally, one of the major sawmills of that time, Weldwood, was owned by Champion International of the United States, and the other, West Fraser, was owned by the Ketchum family of the United States though a majority of its otherwise dispersed shareholders were Canadian.

Up to this time the boreal forests of Canada had been touched more by energy megaprojects, such as the Tar Sands, than by industrial forestry. Relatively small-scale logging by forest companies had been undertaken for a long time. But with all the technological and market changes occurring, and with the decline in availability of commercially useful conifers in traditional northern regions, a new chapter in Alberta's northern history began. Oji, Daishowa and other Japanese companies were at the forefront of the move into Alberta's northern forest, enticed by substantial subsidies, other monetary aids, and vast tenures offered by the government of the time.
Table 1. Historical comparisons, production of pulp and of paper/paperboard in 1975 and 1998, selected countries. (Measured in millions of tons)

\begin{tabular}{|c|c|c|c|c|}
\hline & \multicolumn{2}{|c|}{ Pulp } & \multicolumn{2}{|c|}{ Paper/Paperboard } \\
\hline & 1975 & 1998 & 1975 & 1998 \\
\hline \multicolumn{5}{|l|}{ North America } \\
\hline U.S.A. & 36.8 & 57.9 & 46.2 & 85.9 \\
\hline Canada & 14.8 & 23.5 & 9.8 & 18.7 \\
\hline \multicolumn{5}{|c|}{ Northern and Western Europe } \\
\hline Finland & 5.2 & 11.4 & 4.0 & 2.7 \\
\hline Sweden & 8.3 & 10.5 & 4.4 & 9.9 \\
\hline France & 2.8 & 2.7 & 4.1 & 9.2 \\
\hline Germany & 1.5 & 1.9 & 5.3 & 16.3 \\
\hline Italy & 1.0 & $*$ & 3.6 & 8.2 \\
\hline \multicolumn{5}{|l|}{ Asia } \\
\hline China & 2.9 & 16.5 & 3.6 & 28.0 \\
\hline Japan & 8.6 & 10.9 & 13.6 & 29.9 \\
\hline Korea & $*$ & $*$ & $*$ & 7.7 \\
\hline Taiwan & $*$ & $*$ & $*$ & 4.2 \\
\hline Indonesia & * & 3.4 & $*$ & $*$ \\
\hline \multicolumn{5}{|c|}{ Southern Europe, Latin America, New Zealand } \\
\hline Spain & $*$ & 1.6 & 1.8 & 4.2 \\
\hline Portugal & $*$ & 1.7 & $*$ & 1.1 \\
\hline Brazil & $*$ & 6.7 & $*$ & 6.5 \\
\hline Chile & $*$ & 2.0 & $*$ & $*$ \\
\hline New Zealand & $*$ & 1.4 & $*$ & $*$ \\
\hline
\end{tabular}

Notes: * * volume under 1 million.

Source: Pulp and Paper International Fact and Price Book, 1996 and 2000.

Alberta in its moment of need-which is to say, while the oil industry was failing to provide revenues-did exactly what desperate, developing nations have done: offered substantial incentives to industries to locate in its territory.

Japan is not alone in its global investments. Over the past two decades, Sweden and Finland have adjusted to the new economic realities and to the reduction in tariffs throughout Europe, by establishing paper mills of their own in western Europe-primarily France and Germany. They source their wood supplies in Spain, Portugal, New Zealand, Brazil, Russia, and North America. They have stopped adding to the oversupply of pulp mills in Scandinavia and have substantially reduced their dependence on home forests and the export of lowlevel staples. Western European companies have also started investing in wood supplies beyond Europe so that they can save what is left of their natural forests and reduce the pressure on their plantation forests. American companies have invested elsewhere in order to supplement their domestic supplies and obtain lower comparative prices than they can from northern mills, and also to open up new markets. The 2000 International Pulp and Paper Directory notes that Stora Enso and UPMKymmene are both maintaining investments in Asian locations, while Kimberly-Clark has allied itself with Klabin of Brazil. Further investments are anticipated in Brazil and Chile.

The change in China (Table 1) is extraordinary. China has sustained a massive replanting program throughout the country, but for the most part this has been directed to reduction of erosion, especially near rivers and on hills and mountainsides. It maintains an official logging ban. Its pulp industry in the 1970 s was dependent on recycled paper, wood scraps, and non-wood sources. More recently, it has obtained substantial illicit wood supplies in Burma, though how it currently 
produces nearly 17 million tons of pulp and 28 million tons of paper (compared to Canada's 23.5 million tons of pulp and 18.7 million tons of paper) cannot be deduced from published data.

Korea and Taiwan produce no pulp to speak of, but manage to produce enough paper to supply much of their domestic requirements. In short, the pulp industry is no longer tied to the regions where coniferous forests were once plentiful, and the paper industry is no longer tied to the regions where there are pulp mills.

The market share for pulp from Brazil may still seem small, but the rate at which it is growing is what needs to be understood. These plantations are only beginning to come on stream. Brazil's mill costs are far below costs in any of the northern countries. This is partly due to relatively low-cost labour, but mainly it is due to very low-cost land and fibre supplies. ${ }^{3}$ According to one knowledgeable observer some years ago, Brazil could produce all the world's needed pulp on three per cent of its land area. The forestry director of Celulosa de Asturias S.A. (CEASA), a Spanish company owned by Wiggins Teape, argued that southern companies would in due course buy up northern companies both to claim their customers and to obtain what remains of their long-fibred coniferous forests. ${ }^{4}$

The eucalyptus trees can be grown in straight, even lines, hectare after hectare, on huge areas of relatively flat land. The cloned trees can move into pulpmill grinders directly, eliminating the cost of sawmills and graders. Trees are identical, thus easy to harvest with machinery. And each tree, each hectare produces a much greater yield than its northern competitors.

The growth has been along the sub-tropical to temperate regions of the Atlantic coast from the state of Esperito Santo, where the gigantic Aracruz operations are located, down to Rio Grande do Sul. It is also occurring slightly inland in the states of Minas Gerais in the north, and Paraná in the south. The Brazilian state has provided land, financed much of the construction and offered favourable tax accommodations. Most of this land was used for earlier plantations - cocoa, sugar, and coffee - or for ranching, so the concern about ecological degradation is less pressing than for the moist tropical Amazon region.

But the Amazon is now being opened up for forestry. The famous Jari plantations and mill located at the mouth of the Jari river feeding into the Amazon river, was established in the 1970s, but eventually abandoned as a disastrous investment by millionaire Daniel Ludwig. These plantations have now been regenerated under the company name, Monte Dourado. Having learned from Ludwig's failed experiment, the new company is turning a profit. Other companies, as well, have recently moved into the Amazon where tropical forests will be destroyed for new plantations. ${ }^{5}$

\footnotetext{
${ }^{3}$ Roger Wright, partner in Hawkins, Wright of London, in "What's Happening Out There?" Notes for Canadian Broadcasting Corporation broadcast, 15 June 1992.

${ }^{4}$ Robert A. Wilson, speaker at a market pulp conference in Vancouver, B.C., 1994

${ }^{5}$ These developments are regularly described in Pulp and Paper International, and Pulp and Paper Week.
}

\section{Ecological Issues for Moist Tropical Forests}

Tropical forests in South and Central America and Southeast Asia are generally not very good for industrial forestry. There is a profusion of foliage and very few of the trees have commercial value. Often, many trees are felled in order to get at the few valuable ones, or the trees are used in an inferior grade of pulp. But tropical forests have been ripped out for a vast range of purposes, such as dams, mines, military operations, ranching, and settlement. The denuded land is often beyond reclamation, dried up, transformed into a desert or a patch of imperata (alang-alang) grass. This occurs because the nutrients are in the foliage. Clearcutting removes them, and also removes the canopy that otherwise catches the rain and provides shade from the sun. The gene pool, not only for the vegetation, but as well for the extensive fauna, is destroyed. If the hills or watershed regions are logged, downstream flooding results. There are local atmospheric changes, and of course, a loss of animal habitat and biodiversity.

In some tropical regions, strip-logging rather than clearcutting is used. This ensures that some of the moist forest remains in place, but unless the logged strips are very thin, this method does not ensure the vitality of the ecosystem and frequently causes severe damage to animal habitat.

The Tropical Forest Action Plan was adopted in 1985 by the World Bank, FAO, and other international agencies, ostensibly with a view to stopping the logging of tropical forests. The objective was to subsidize the development of plantations on marginal land. Such land can sometimes be reclaimed with the aid of expensive fertilizers and irrigation. From the point of view of forest companies, however, it is cheaper to replant trees immediately after logging a tropical forest though that land also requires fertilizers. Unwanted species are generally poisoned immediately after clearcutting, but the poison then enters the water table, along with chemical fertilizers. The comparative costs, in any case, favour the planting on former tropical forest land, rather than land that has already baked dry or otherwise lost its capacity to sustain vegetation.

By way of example, several of the world's largest pulp mills are now located on the Indonesian island of Sumatra. Indah Kiat Pulp and Paper noted in news reports that its initial source of wood would be "virgin forest on the company's 300 000-ha concession," (Pulp and Paper International 1994) which it expected to replace with plantation species. Indeed, according to industry observers, it was rushing to cut the forest in its concession before the year 2000, so it could meet the target date adopted at the Rio Earth Summit Conference for stopping the logging in tropical forests (Bayliss 1994, Pulp and Paper International 1994). Another example: the director of the forestry economics unit in Malaysia's Forestry Department approvingly discussed with reporters "the wisdom of cutting down natural tropical forests and re-afforesting with fast-growing species," informing them that this was a matter of "urgency" for the government (Sirin 1990).

\section{Social Issues in Southern Countries}

The forest industry in southern regions may also create severe social problems. Forests were once the habitat for indigenous people who travelled in small bands, cultivating and planting subsistence foods on small areas for short periods of time. The land would maintain yam and other such crops for up to three years, and when its yield diminished, the band moved 
on to another area, not returning to the same site for two or three decades. Such bands normally had extensive knowledge of foliage, including medicinal knowledge. Whether through herbal medicines or more severe methods, they kept their populations down.

But once the forests were invaded by industrial societies, initially for settlements and earlier plantation crops, these indigenous people and other landless farmers were pushed out and treated as criminals when they tried to return to their traditional activities. I have seen these poor people huddled in miserable conditions at the margins of the forests on Sumatra and in Kalimantan. Cultures destroyed, they can no longer control population growth; they are often starving; they barely survive. You may have recently read newspaper accounts of Dyak attacks on local settlers. Unfortunately, their victims are transmigrants forced to leave the overcrowded island of Java to live on poor land-plots next the forests, and these are not the people who have caused the misery of the Dyak. Nor are they profiting from the take-overs of Dyak traditional forest territories. But the Dyak have no way to distinguish between rich and poor Indonesians; they are simply and finally striking out at whomever is displacing them on their land. A few years ago, the Penan of Sabah and Sarawak staged similar resistance battles. These poor people are easily silenced by logging companies as well as by governments.

In a company town in Brazil, I was shown a pharmacy that was selling herbs for medicinal purposes. Indigenous knowledge of these herbs had been tapped by ethnobotonists and appropriated by pharmacologists for the benefit of the pharmacy industry. The natives were nowhere in evidence in the mill or townsite.

With the development of industrial forestry in the Philippines, Indonesia, Papua-New Guinea, Thailand, and Malaysia, there is a marked increase in corruption and military control. This may not be the intentional result for forest companies, but is rather the unintended-yet tolerated-outcome of the process of obtaining land, working logging concessions, and building mills. In Indonesia, the government ensured that military officers were the silent partners for companies that were given concessions - they had to be paid off in return for repressing native people and farmers. In Brazil the farmers have to be persuaded to sell their land or else to grow eucalyptus crops for the companies: this is much less repressive than in the Asian forest regions, but it does have social consequences for small towns and farmers.

We are always told that there are multiplier and trickle-down effects for developing countries with investment funds coming from outside. The multipliers tend to accumulate in the pockets of the already wealthy, an observation more eloquently stated by the former forestry director of FAO, Jack Westoby, who bluntly terms deforestation in tropical countries "genocide." Indeed, he argues that "there are millions now living on the edge of famine in tropical countries that once were well forested but from which the forests have now virtually disappeared" (Westoby 1989). He refers specifically to forestry operations in moist tropical regions.

\section{Plantations in Southern Regions}

Plantations in tropical, sub-tropical, and southern temperate regions may also have severe ecological consequences. They are monocultures. They provide no habitat for any other living creatures, and there is no biodiversity. They have shallow canopies, and are heavy users of water so they tend to lower the water table of the region, or they require steady irrigation. They cause microclimate changes, and may cause macroclimate changes - that charge is still under debate. They definitely cause local air temperatures to increase. They are renewable but they have been in existence too short a time for anyone to know how many rotations are possible on the diminished soils. They require heavy doses of fertilizers and these chemicals enter the water system with consequences still unknown. Also unknown at this stage are their capacities to withstand pests and diseases. This is because most of the plantation species are exotic and so are enjoying a brief hiatus in infections and infestations. When their presence becomes normal in the region, such infestations will inevitably develop.

Even with all of these ecological problems, plantations are probably the future source for the world's pulp. Jaakko Pöyry, a Finnish engineering firm that does feasibility assessments for proposed pulp mills all over the world, including the ALPAC mill in Alberta, has estimated that by the year 2020, fast-growing plantations would supply nearly 20 per cent of the world's industrial hardwood production and 15 per cent of the world's softwood production. ${ }^{6}$ There are even more generous estimates by other industry observers.

Plantations in future are likely to be less damaging to the earth than the continued logging of natural forests in both temperate and tropical regions. Research underway at several stateof-the-art operations in the sub-tropical and temperate regions of Brazil may overcome some of the ecological hazards. For example, Aracruz and Klabin, both very large companies, intersperse tropical, pine, and plantation eucalyptus plots to reduce the problems associated with clones and monocultures. Several companies are experimenting with permissive undergrowth, both to enrich the soils and to provide either subsistence food or fuel for local populations. The pulp mills have numerous precautions against atmospheric and water pollution. I do not mean to suggest the problems are solved, but I do think that, as long as the world demands wood-based pulps, the plantations on these lands may be less damaging than other current practices.

While plantations do not solve the problems identified by Westoby, they do provide some benefits for workers, particularly for those who obtain longer duration jobs with some skill-training. In Brazil, several of the pulpmill companies have created townsites with recreation facilities, small hospitals and clinics, schools, crèches and kindergartens for the workers and their families. Since these people would otherwise be very poor, this new source of employment is extremely important. In short, there are benefits, and there are costs, and unfortunately, the costs are generally not borne by those who receive the benefits. It may be significant that the most progressive of the Brazilian companies are majority-owned in Brazil. But that will not carry over across the board, because the Indonesian firms are majority-owned in Indonesia- and these are not, shall we say, model companies.

Plantations in the more temperate regions-Spain, Portugal, the southern United States, New Zealand, Australia, Chile, Argentina, and South Africa at the present time - are expanding in acreage and impact. While ecological consequences attend all monoculture plantations, and countries as well as companies have to decide whether these are the best use of land, these

${ }^{6}$ Presentation at conference in Victoria, B.C., September, 1996, "Sustaining Ecosystems and People in Temperate and Boreal Forests." 


\begin{tabular}{lccc}
\hline \multicolumn{4}{l}{ Table 2 } \\
\hline Year & Wood pulp & Newsprint & Printing/writing papers \\
\hline 1975 & 32.7 & 67.3 & 6.3 \\
1980 & 34.1 & 62.4 & 9.8 \\
1990 & 31.6 & 57.4 & 13.0 \\
1995 & 30.2 & 50.0 & 14.0 \\
1996 & 29.6 & 49.4 & 14.1 \\
1997 & 28.1 & 47.9 & 11.0 \\
1998 & 27.2 & 43.2 & 11.4 \\
\hline
\end{tabular}

Source: Canadian Pulp and Paper Association, Reference Tables, 1999.

operations are undoubtedly the source of fibres for a very different industry from that earlier dominated by northern companies that relied on nature's gifts for their wealth.

\section{International Division of Labour}

Since the decline of imperialism, industrial countries have maintained their dominant positions more through investment and trade than through military presence- though military force has continued to back up the major powers. With the changing locations of forestry, the nature of the investments and trade have also changed. Several multinational engineering firmsJaakko Pöyry and Econo of Finland, H.A. Symons and Sandwell of Canada, most notably - have become the world's experts in examining the engineering feasibility of constructing pulp mills. Other companies, or wings of the same ones, study the markets for greenfield operations; Japanese and European companies manufacture the machinery; still other northern companies provide know-how about obtaining and training a labour force, marketing techniques, and other information essential to the start up of a new mill. These are big businesses. They are replacing the old-fashioned newsprint and wood-products companies that used to sell their wares in developing countries. So the south is moving into the pulp business, and the north, Alberta notwithstanding, is securing its dominant position in the linked knowledge-based fields.

What does this mean for traditional forest companies in the north? Canada, heavily dependent on exports, sold more pulp and also more paper in 1998 than it did in 1975. But it actually sold a smaller proportion of the world's total of pulp and newsprint than it did a quarter of a century ago. Its export of higher-grade papers finally increased for a brief decade in the 1990s, and has since declined. Considering its substantial quantities of pulp this proportion of higher-grade papers is not very remarkable.

In fact, Canada's volume of production of fine papers in 1998 (the most recent year for which comparable information is available) amounted to less than half as much as the combined Nordic countries (Table 2). Latin American countries (with Brazil much the largest player) produced three-fifths as much as Canada, and Asian countries together produced two and a half times as much. The United States and Western Europe produced about four times more than Canada (CPPA 1999).

As was the case earlier, Canadian companies are not international giants, though often their parent companies in the United States, Japan, and Europe have high ranks. In fact, there are fewer large or even medium-sized Canadian-owned companies today than in 1975. Individual plantation companies such as Sappi in South Africa, Klabin in Brazil, and the Siner Mas group in Indonesia (owners of Indah Kiat) have recently been listed in the top 20 world listings of all companies by production volumes, with no Canadian companies included. Ranks by sales are regularly dominated by Swedish firms such as Stora Enso and Svenska Cellulosa (SCA), Finnish companies such as Kymmene and Metsä-Serla and Enso-Gutzeit, American giants such as International Paper, Georgia-Pacific, Stone Container and Weyerhaeuser, and Japanese companies such as Oji, Nippon, Daio, and Daishowa. ${ }^{7}$

So, Canada has not travelled far along the restructuring route, not as far as the Nordic countries and Western Europe. The companies that will survive have already begun their transformation. They will be upgrading their product mix, moving away from the production and export of raw materials and low-level staples. To upgrade their mills, they will have to undertake new contracts with labour, move away from regional bargaining, rigid job definitions, and assembly-line production. They need to create a much more flexible operation, with labour that can move from one job to another and work in teams. Some companies will not survive, or will, as in the case of Gold River on the West Coast of Vancouver Island, simply close down and abandon their mills. Unemployment in forest regions will continue to increase. This is not only because some companies cease operations, it is even more because the restructuring will mean much smaller work forces in remaining mills. The longstanding belief in forestry regions such as British Columbia, that forestry would provide permanent employment and communities has already given way to impoverished regions, shrinking towns, and substantial unemployment.

This is not to say that the forest industry in B.C. and other traditional regions will disappear. Lumber will remain a major commodity and companies that focus on it will survive, especially if they can ever obtain a better lumber agreement with the United States. Alternatively, they will focus on the production of other solid wood products and higher-grade papers, looking for new, niche markets. Various kinds of paperboard, and engineered wood will become more important features of the industry. In summary, there will be a complete restructuring of the industry and what comes out will be much smaller and more specialized.

The situation in Alberta is somewhat different, because the greenfield mills established here are just beginning on the upward curve, producing mostly pulp, and some are tied to Japanese papermakers. At the moment, these mills, together with the other companies on the prairies, are producing about as much pulp as B.C. produced in 1975, and about the same amount as is produced in the combined Atlantic provinces. Quebec, B.C., and Ontario are still much more productive, but Alberta is on a growth curve, and the leaders have stopped growing. So, I suppose we can call it a sunrise industry here.

But is this a glorious sunrise? I do not applaud the logging currently going on in Alberta's boreal forest. In my view, a forest that needs upwards of 70 years to re-grow after clearcutting, and 120 for the spruce trees, is not a forest that can attract investment in high-quality reforestation and continuing thinning and silviculture. By the time the original growth is logged over, the mills will have reaped good returns on their investment and will also have established wood fibre sources in faster-growing regions. By then, of course, we may have alternative fibre sources altogether; they are already being devel-

${ }^{7}$ Pulp and Paper International Fact \& Price Book provides rankings by sales and by volume on an annual basis. The companies named here have regularly appeared on those lists since 1995. 
oped. I, personally, am not convinced that the massive logging presently going on in the boreal forests of Alberta will result in a long-term development. Small-scale operations are much more suitable to a fragile environment. To me, the ecological and social costs appear to be substantial.

Those costs appear to include the loss of an important carbon sink, biodiversity, habitat for the fauna, and a unique ecology. They appear to include unknown levels of pollution in the river systems, particularly the Athabasca and the Peace Rivers. They apparently include water depletion at a time when scientific voices are warning of the probable development of draught conditions on the prairies. On these various ecological grounds I use the word "appear" because we do not know, neither the companies nor the scientists, what are the long-term impacts of massive clearcutting of boreal forests. Nor, indeed, can we know those, because ecological systems are extremely complex, far larger than can be studied in laboratories under controlled conditions. Further, they outlast a generation of humans, and conclusive studies would require longitudinal examinations beyond a generation's capacities and also beyond the fiscal capacities of most societies. As the well established ecologists, Ludwig, Hilborn, and Walters, argued in a seminal paper some years ago, we are probably better informed about what happens to ecological systems by looking at the history of resource exploitation, than by relying on scientific evidence (Ludwig et al. 1993). And as you know, the history is dismal indeed. We have allowed our greed and our technological expertise to determine our rates of exploitation; if we cannot learn from science, then let us finally and humbly learn from history. The lesson is clear: when we do not know what we are doing to the earth, the precautionary principle is our appropriate choice.

I am not persuaded by the argument about clear-cutting being the equivalent of fires and equally essential to providing the conditions for the seeds to germinate. Fires are very different in their impact on forests; they are essential to the boreal forest, but clearcutting does not have the same functions. Furthermore, fire suppression is, in itself, a serious threat to the environment. Based on what I have learned to date, I think the ecological issues are too many to justify the economic activity.

On social grounds, the costs include tribal lands of indigenous people, displacement of alternative activities and smallscale lumber operations, loss of rural opportunities in small northern towns and farming areas, and the loss of a place where humans enjoy aesthetic and spiritual enrichment. Although there was a promise of employment to local people, and some employment has certainly been provided in the large woodlands and mill operations, modern operations are capitalintensive, and labour is not in high demand. As well, the bulk of the jobs require prior skills and education; those who most need employment are not hired. In short, these resource megaprojects intensify poverty in rural areas, even though they materially enrich management and skilled workers. The revenues that are reaped by governments become sources of recompense via welfare- and so the observer wonders if the cycle is, on balance, a net social and economic benefit.

\section{Toward Sustainable Alternatives}

If we want to save the remaining natural forests of the world, whether because they are essential carbon sinks, or because they are the vital habitat for the flora and fauna that populate the earth, or simply because they are sources of peace and beauty, then we must seek sustainable alternatives for both the raw material and its products.

On ecological grounds, construction that uses wood may be preferable to existing alternative materials such as steel, plastics, and concrete. But the extraction of wood, especially in the tropics, depletes the forest. To the best of my knowledge, we have no environmentally sustainable substitute material on the horizon. A different solution is to decrease our demand for wood by reducing the space and accoutrements of our dwellings and offices, and that would be consistent with a more general reduction in the ecological footprint of North Americans and Europeans that ecologists urge us to make. I confess I see little likelihood of this occurring voluntarily, though it is bound to occur involuntarily at some point in the future.

Logging for pulp fibre depletes the forest, and, as well, its products add substantially to the production of waste. Waste in and of itself is a serious pollution problem for our earth. The electronic office did not decrease our use of paper. On the contrary, it increased it - we now download much that we would earlier have read and left on library shelves. There are nonwood sources of fibre that pulp mills in other countries have used for many decades, such as bamboo, rags, and sugar bagasse, and we could recycle more newsprint and other paper. Kenaf, akin to hemp, is usable, along with other vegetable matter, but it is vulnerable to changing weather conditions, and harvesting is labour-intensive. I imagine it would become much more utilizable with a little human ingenuity. So we will have to put our brightest minds to devising new sources of fibre or new ways of producing less damaging equivalents to newspapers, toilet tissues, fine papers, and all the other useful items that we use and still want.

I am not arguing against the forest industry per se. I am arguing against the mass production and consumption of wood and wood products, on a scale that is far too great for the sustenance of fragile ecosystems. I believe we could adjust our standard of living to a much smaller scale of resource exploitation and simultaneously reduce our production of pollution and waste. I think, indeed, that we must do so if we want the earth to survive well into the future.

Humans are ingenious, and once the bright minds of students are put to finding solutions to the destruction of forests and the proliferation of waste, the sooner we will wean ourselves of dependence on wood. We will create environmentally sustainable industries in the future both because we must if the earth is to survive, and because to do so is a wonderful challenge.

\section{References}

M. Bayliss. 1994. Papermaker, Oct.: 31-35.

Canadian Pulp and Paper Association. 1999. Canadian Pulp and Paper Association Reference Tables. Table 14: Production, Writing Papers. Montreal, Quebec.

Ludwig, D.R. Hilborn and C. Walters. 1993. Uncertainty, Resource Exploitation, and Conservation: Lessons from History. Science 260(4): 17-18.

Marchak, M.P., S.L. Aycock and D.M. Herbert. 1999. Falldown. Forest Policy in British Columbia. David Suzuki Foundation and Ecotrust Canada, Vancouver.

Pulp and Paper International. 1994. Oct.: 24.

Sirin, L.M. 1990. Malaysia In Asian Productivity Organization. Forestry Resources Management. pp. 247-268. APO, Tokyo.

Westoby, J. 1989. Introduction to World Forestry: People and their Trees. Basil Blackwell, New York. 